\title{
Factors influencing travel to Islamic destinations: an empirical analysis of Sunan Ampel religious tourism area Surabaya
}

\author{
Siti Rahayu \\ University of Surabaya, Surabaya, Indonesia
}

\begin{abstract}
The purpose of this paper is to analyze the influence of travel motivation, Muslim-friendly amenities and lifestyle, destination image, and the quality of service on Indonesian travelers' intentions to visit Sunan Ampel religious tourism area Surabaya. Data were collected through self-administrated questionnaires that were distributed randomly to Indonesian travelers at Sunan Ampel Religious Tourism Area Surabaya and some tourist areas around Surabaya. Statistical analyses such as multiple linear regression and descriptive analysis were used to analyze the data. Travel motivation and destination image had significant effects on the Indonesian travelers' intention to visit Sunan Ampel religious tourism area Surabaya. Meanwhile, Muslim-friendly amenities and quality of service did not affect Indonesians' travel intentions.
\end{abstract}

Keywords: destination image, travel motivations, religious tourism, tourist satisfaction, travel intentions

\section{INTRODUCTION}

Today, tourism is becoming a global leisure activity which is popular and very important for many countries. The tourism business flow is massive to meet the needs of tourist goods and services (Ukessays 2014, Khan et al. 2013). These services include taxis, airlines, buses, accommodation, foods, hotels and resorts, entertainment, and shopping centers (Rahman 2014).

Tourism becomes a major asset and international attention. Each country has its own tourism ministry and council. Each country counts the number of tourists each year, how much money is spent and how long the tourists stay in a certain place (AlAmin 2002). Tourism raises cultural exchanges and learns the customs and traditions of people while traveling to other countries. Tourists recognize culture, customs and traditions, and encourage interactions among nations in the world. Religious tourism is a form of tourism that is exclusively motivated for religious reasons (Duman 2012 in Bazazo et al. 2017).

Religious tourism has been very popular in recent decades, as well as being an important segment of international tourism. Consistent growth in this mar- ket segment has become a global tourism trend (Jaelani 2017).

Nowadays, Muslim tourists are rising faster than the global tourist growth rate. The value of Muslim tourist spending was US\$ 126 billion in 2011, and is estimated to reach US\$ 192 billion by 2020 . The Muslim population is projected to grow around $35 \%$ from 2010 - 2030 (Jafari \& Scott 2013 in Eid \& ElGohary 2015).

The trends of Islamic tourism make product development and marketing efforts are designed and directed for Muslims. Muslim tourists' motivation is not always or entirely religious. Participants may join the same holiday experience as non-Muslims, although within the parameters set by Islam. In addition, the destination does not have to be the location where full Sharia (i.e. Islamic law) is enforced (Zamani-Farahani \& Henderson 2010 in Bazazo et al. 2017).

Islam is regarded as a comprehensive way of life because its teachings cover all possible affairs of human life. The Quran in various ways gives special attention to tourism, and its attitude towards tourism is considered one of the great blessings of God. In the Quran, Muslims travel to appreciate the beauty of the world as God's creation as well as visit friends and family. Religious buildings, rituals, festivals and 
religious events are important tourist attractions for those who join certain belief system (Henderson 2003 in Fahim \& Dooty 2014).

The Muslim tourism segment is currently considered to be the marketer's target market. Religion is an important factor in the decision making related to travel destination. Therefore, ensuring that the Islam attributes are available at the destination is very critical. The availability of these attributes can satisfy Muslim tourists and encourage return visits. Muslims who strive to the teachings of Islam directly and indirectly have an impact on their decisions regarding vacation and travel plans (Zamani-Farahani \& Henderson 2010 in Bazazo et al. 2017). Planning on Muslim tourist market should be in accordance with Sharia in regulating all matters relating to tourism activities (Ismail \& Bator 2010).

This research was based on Nassar's research et al. (2015) who analyzes the influence of travel motivation; Muslim-friendly amenities and lifestyle; cognitive and affective destination image and service quality towards Kuwait tourist intention to visit Islamic tourist destinations. Nassar et al. (2015) shows that travel motivation as well as cognitive and affective image have the greatest influence on the desire of Kuwait tourists to visit Islamic destinations. In contrast, Muslim-friendly amenities and quality of service have no effect on Kuwait tourist decisions.

Referring to Nassar et al. (2015), this research focused on Sunan Ampel religious tourism area in Surabaya city. This area is an Islamic tourism area in East Java visited by tourists from various countries and regions in Indonesia. The facilities in this area are: Sunan Ampel tomb, five Archways, Holy Ampel Gubah market, Sunan wells, and Ampel Mosque. In this area, there are so many street vendors or places to eat that serve a variety of typical Arab foods.

Many tourists visit the area. At the end of Ramadan month, for example, the area is visited by 10,000 - 20,000 people in one day. In addition to intending prayer and dhikr in a quiet place, many come for a pilgrimage to the Sunan Ampel tomb. Foreign tourists come from China, France, Netherlands, Italy, Malaysia, Saudi Arabia, Japan, Brunei Darussalam, Philippines, Germany, Greece, New Zealand, Korea, and Japan. Generally, they see the Ampel mosque building and conduct a pilgrimage to the Sunan Ampel tomb. Many tourists who come just to shop Muslims' various kinds of good needs.

Based on the Sunan Ampel religious tourism area conditions, many visiting tourists are motivated to make a pilgrimage and pray. The high number of tourists visiting Sunan Ampel urged the government to rearrange this area in order to satisfy the tourists. Various facilities including the trade area of Islamic attributes are prepared to make tourists feel comfort- able visiting this area. Muslims travel to Islamic historic places aims to relax and learn about the history of Islam. According to Eickelman \& Piscatori 1990 in Khan et al. 2013), Muslims travel to visit friends and family, appreciate the beauty of God's creation and encourage unity among the Muslim community. According to Henderson (2003), they also often travel for holiday (Nassar et al. 2015).

Based on the Sunan Ampel religious tourism area conditions, this research focused on the influence of travel motivation, Muslim-friendly amenities and lifestyle, cognitive and affective destination image and service quality to domestic tourist intention to visit Islamic tourism destinations in Sunan Ampel religious tourism area Surabaya.

The purpose of this research was to know the influence of travel motivation; Muslim-friendly amenities and lifestyle; cognitive and affective destination image and service quality towards the intention of domestic tourists to visit Islamic tourism destination of Sunan Ampel religious tourism area Surabaya. This study was expected to provide an explanation of some variables that influence the desire of tourists visiting this area. This would facilitate the management of this tourist area to prepare various facilities for the comfort and satisfaction of visitors.

\section{RESEARCH METHODS}

This research was a causal research to know the influence of destination image, Muslim-friendly amenities and lifestyle, service quality to travel intention. The data used were primary data. Data were obtained through questionnaires to get respondents' responses to questions in the questionnaire.

The data were then processed by multiple regressions. The dependent variable in this research was travel intention, while the independent variables were destination image, Muslim-friendly amenities and lifestyle, and service quality.

The population in this study was domestic tourists who visited the Sunan Ampel religious tourism area Surabaya. Characteristics of respondents in this study were male and female with the minimum education level of high school, domiciled in Surabaya and outside Surabaya and at least visited Sunan Ampel area once in the past year.

\section{RESULT AND DISCUSSION}

Table 1 shows the coefficient of determination value (R-square) in this study of 0.29. This figure shows that travel motivation (TM), Muslim-friendly amenities and lifestyle (MA\&Life), destination image i.e. 
cognitive image (CI) and affective image(AI), and service quality (SQ) have an influence on travel intention of $28.6 \%$. The rest is influenced by other variables outside this regression model.

Data processing produces regression equations as shown in Table 2 . The equation shows that the dimensions of travel motivations, destination image (cognitive and affective image), and service quality have a positive influence on travel intention. Meanwhile, Muslim-friendly amenities and lifestyle hve a negative influence on travel intention in Sunan Ampel religious tourism area Surabaya. This shows that the desire of tourists to visit the area is influenced by motivation. This is indicated by the number visitors to the area never diminishes over time. Sunan Ampel figure as one of the guardians of 9 Islamic religious propagators becomes a strong motivation for tourists visiting this tourist area.

Image of this tourist area is also very good among Muslims. Many Muslim tourists come to visit for pilgrimage and prayer. As a tourist area that has many visitors, the government is also trying to rearrange this area in order to provide good services for visitors. The desire of tourists is stronger to visit because of the religious motivation and not too concerned with various other attributes such as accommodation, food, and beverages available in this tourist area.

Table 1. Analysis of the coefficient of determination of a multiple linear regression.

\begin{tabular}{lllll}
\hline Model & $\mathrm{R}$ & $\begin{array}{c}\mathrm{R} \\
\text { Square }\end{array}$ & $\begin{array}{l}\text { Adjusted R } \\
\text { Square }\end{array}$ & $\begin{array}{l}\text { Std. Error of the } \\
\text { Estimate }\end{array}$ \\
\hline 1 & 0.54 & 0.29 & 0.26 & 0.93 \\
\hline
\end{tabular}

source: processed data using SPSS Windows 16.0.

Table 2. Analysis of multiple regression equation result.

\begin{tabular}{lll}
\hline Model & \multicolumn{2}{l}{ Unstandardized Coefficient } \\
& $\mathrm{B}$ & Std Error \\
\hline (constant) & -0.42 & 0.70 \\
TM & 0.25 & 0.10 \\
MFAL & -0.11 & 0.13 \\
CI & 0.67 & 0.18 \\
AI & 0.35 & 0.14 \\
SQ & 0.08 & 0.19 \\
\hline
\end{tabular}

source: processed data using SPSS Windows 16.0.

Table 3. Result of F test calculation.

\begin{tabular}{llllll}
\hline Model & $\begin{array}{l}\text { Sum } \\
\text { Square }\end{array}$ & df & Mean & F test & Significance \\
\hline Regression & 49.62 & 5 & 9.92 & 11.54 & 0.00 \\
Residual & 123.86 & 144 & 0.86 & & \\
Total & 173.47 & 149 & & & \\
\hline
\end{tabular}

source: processed data using SPSS Windows 16.0.
The result of F-test calculation in table 3 shows that travel motivation, Muslim-friendly amenities and lifestyle, cognitive image, affective image and service quality influence travel intention.

The result of t-test calculation in table 4 shows that travel motivation, cognitive image, and affective image have a significant influence on travel intention. Meanwhile, Muslim-friendly amenities and lifestyle, as well as service quality, do not significantly affect travel intention.

Table 4. Result of t test calculation.

\begin{tabular}{lllll}
\hline Variable & $\mathrm{t}$ & $\mathrm{Sig}$ & Description & Beta \\
& value & & & \\
\hline TM & 2.58 & 0.01 & Significant & 0.20 \\
MA\&Life & -0.09 & 0.39 & Not- Significant & -0.07 \\
CI & 3.77 & 0.00 & Significant & 0.35 \\
AI & 2.57 & 0.01 & Significant & 0.21 \\
SQ & 0.43 & 0.67 & Not- Significant & 0.04 \\
\hline
\end{tabular}

source: processed data using SPSS Windows 16.0.

\section{CONCLUSION}

The results of this study indicate that the desire of tourists visiting Sunan Ampel area is influenced by travel motivation, Muslim-friendly amenities and lifestyle, cognitive image, affective image, and service quality. However, partially Muslim-friendly amenities and lifestyle, as well as service quality, have no significant effect on travel intention.

This research was conducted in a religious tourism area. Sunan Ampel religious tourism area Surabaya is one of a series of religious tourism areas in the Java Island because Sunan Ampel is one among nine guardians who spread Islam in Java. The next researcher can expand the research with a wider object because there are many religious tourism areas in Indonesia. The results of research on religious tourism area are expected to be useful for government and religious tourism destination managers to prepare all the attributes needed for the comfort and satisfaction of tourists.

\section{REFERENCES}

Al-Amin, H. 2002. Religious tourism in Islamic heritage. Islamic Tourism 2: 32-36.

Bazazo, I, Elyas, T. Awawdeh, L, Faroun, M \& Qawasmeh, S. 2017. The impact of Islamic attributes of destination on destination loyalty via the mediating effect of tourist satisfaction, International Journal of Business Administration 8 9(4).

Eid. R. \& El-Gohary, H. 2015. Muslim tourist perceived value in the hospitality and tourism industry. Journal of Travel Research 54(6): $774-787$. 
Fahim. S.T. \& Dooty, E.N. 2014. Islamic tourism: in the perspective of Bangladesh. Global Journal of Management and Business Research: Real Estate Event \& Tourism Management 14(1).

Ismail. M.N. \& Bator, M. 2010. The impact of destination attributes on Muslim tourist's choice. Int. J. Tourism Res.

Jaelani, A. 2017. Halal tourism industry in Indonesia: potential and prospects. Munich Personal RePEc Archive (MPRA) Paper.

Khan, A.H., Haque, A., \& Rahman, M.S. 2013. What makes tourists satisfied? an empirical study on Malaysian Islamic tourist destination. Middle-East Journal of Scientific Research 14(12): 1631-1637.

Nassar. M.A., Mohamed, M.M., \& Yvette R. 2015. Factors influencing travel to Islamic destinations: an empirical analysis of Kuwaiti Nationals. International Journal of Culture, Tourism And Hospitality Research 9(1): 36-53.

Rahman, M.K. 2014. Motivating factors of Islamic tourist's destination loyalty: an empirical investigation in Malaysia. Journal of Tourism and Hospitality Management 2(1): 6377.

Ukessays. 2014. Islamic attributes of destination on tourists motivation. Retrieved from http://www.ukessays. com/essays/tourism/islamic-attributes-of-destination-on tourists-motivation-tourism-essay.php. 